Journal of African Real Estate Research

Volume 4, Issue 1

\title{
Causal Relationship between N-REIT's Dividend Yield and Money Market Indicators
}

Olusegun O. Olanrele ${ }^{1,3}$, Tomisi O. Adegunle ${ }^{1,2}$, Oluwatosin B. Fateye ${ }^{1,2}$, C. A. Ajayi ${ }^{2}$, and Rosli Said ${ }^{3}$

${ }^{1}$ Department of Estate Management and Valuation, Moshood Abiola Polytechnic, Nigeria.

${ }^{2}$ Department of Estate Management, Obafemi Awolowo University, Ile-Ife, Nigeria.

${ }^{3}$ Department of Estate Management, University of Malaya, Kuala Lumpur, Malaysia.

To cite this article: Olanrele, O.O., Adegunle, T.O., Fateye, O.B., Ajayi, C.A. \& Said, R. (2019). Causal Relationship between N-REIT's Dividend Yield and Money Market Indicators. Journal of African Real Estate Research, 4(1), pp.71-91. DOI: 10.15641/jarer.v4i1.720.

\section{This article was presented at the 2018 African Real Estate Society Conference in Abeokuta, Nigeria.}

\begin{abstract}
This paper examined the relationship between the Nigerian Real Estate Investment Trusts (NREITs) and Money Market Indicators (MMIs) which comprise of: Currency in Circulation (CIC), Broad Money Supply (BMS), Corporate-private Sector (CPS), Prime Lending Rate (PLR) and Treasury Bill Rate (TBR). Data for the N-REITs were sourced from the annual published report of SkyeREIT (an indirect real estate investment vehicle of Skye Shelter Fund Plc), while that of the MMI were sourced from the quarterly published bulletins of the Central Bank of Nigeria (CBN) and the National Bureau of Statistics (NBS) for the period 2008-2017. The study adopted the Co-integration test, Vector Autoregressive (VAR) and Vector Error Correction Model (VECM). The data collected passed the stationary test at $p$-value of $p<0.05$ which implies that the data is fit for Granger Causality Model (GSM) in a VAR environment. The co-integration test at 5\% confidence level shows the existence of a partial long-run relationship at p-values of $0.0003,0.0292$ and 0.0297 respectively at the first three orders, while the Max-Eigen rank test was significant at the first order (none) with a p-value of 0.005 . The results of the VAR and VEC models showed that CPS, PLR and TBR, with chi-square values of 11.748; 16.589; and 34.778 respectively, significantly affected the performance of N-REITs, while the PLR (4.5798) had a long-run significant effect. The findings provide decision caution for investors, analysts and capital market players when considering investment on securitised real estate assets.
\end{abstract}

Keywords: Causality; Dividend Return; Money Markets Indicators; REITs; Nigeria 


\section{Introduction}

Monetary policy is part of (and a tool of) macroeconomic policy. It is a set of measures and policies that is used to influence money supply through various adjustments of requirements for bank reserves, interest rates, open market operations and sale of government investment options and foreign exchange. The Central Bank of Nigeria (CBN), which was established in 1958, has been saddled with the responsibility of creating monetary policy for Nigeria. Through the CBN Monetary Policy Committee (MPC), the bank has been making such policy from its inception. A regime of direct control was adopted till 1986 after which indirect control was adopted using several measures (Bodunrin, 2016). The monetary policy instruments of the CBN include the Broad Money Supply (BMS), usually referred to as $\mathrm{M}_{2}$, Prime Lending Rate (PLR) (interest rate), Open Market Operation, Credit to Corporate Sector, among others (CBN, 2016). Monetary policy is designed towards two objectives; price stability and sustainable economic growth (Ezema, 2009). The monetary policy of a nation is either an expansionary or contractionary economic measure taken by the central bank or other agencies to administrate the supply of money and interest rates so as to influence output, employment and prices, with a view to achieving the macroeconomic objectives of the government. Expansionary policy tries to stimulate economic activity and reduce unemployment while contractionary policies are geared to limit the money supply to mitigate against inflation (Hall, 2010 cited in Adegbite \& Alabi, 2013). The CBN is primarily responsible for the management of the monetary policy in the country.

The money market, under the regulation of the country's monetary policies, is central to both debt and equity finance of capital projects like Real Estate Investment Trusts (REITs). Some measurable variables used as representation of the money market, identified by the $\mathrm{CBN}$, comprise the Central Bank indicative rate, monetary policy rate, Treasury bill, BMS, Currency in Circulation (CIC) and other short-term interest rates in the financial market. These include inter-bank call rates, savings, and other fixed deposit and lending rates. Whereas, BMS comprises savings and time deposits (quasi money), narrow money supply refers to CIC; including nonbank public and demand deposits. The identified MMIs have been proven to have effects on investment return including property securities and REITs, as shown in a similar investigations in other markets (developed and emerging). See, for example: Onyewu (2012); Unus (2012); Adegbite and Alabi (2013); Ito (2013); Fatnassi et al. (2014); Lee and Lee (2014); Udude (2014); Ngerebo-A (2016); Yan (2019).

The relevance of money market instruments and policies to securitised investment in stock exchange markets has been a subject of interest in recent years. Previous studies that investigated the factors responsible for REIT return performance established that beyond the external dynamics of government policies and other operating environments, there are macroeconomic factors that influence relationships in real estate investment return performances (Olanrele, Said, \& Daud, 2014; 2015). A study by Oyewole and Ajayi (2013) identified GDP, interest rates, and employment 
rates as the most significant macroeconomic factors influencing the performance of office real estate. However, the study did not consider the REIT market. Daud et al. (2012) also concluded that any factor that affects property income will affect REIT dividend performance. Inflation is another macroeconomic factor that has been investigated. The common perception of real estate investment as a good hedge against inflation, making real estate an attractive investment option, has been subjected to discussion in the literature with diverse results emanating thereto (Hoesli, 1994; Barkham, Ward \& Henry, 1996; Hamelink \& Hoesli, 1996; Hoesli, Matysiak \& Nanthakumaran 1996; Newell, 1996; Hamelink, Hoesli \& MacGregor, 1997; Bello, 2005; Manni \& Teng, 2007; Wurstbauer \& Schafers, 2015; Ma'in et al., 2016).

Most studies have limited their investigations to macroeconomic variables of inflation, interest rate, GDP, capitalisation, exchange rate or global oil price volatility (Oyewole \& Ajayi, 2013; Dabara, 2015; Diala, Kalu \& Igwe-Kalu, 2016). However, Oni, Emoh and Ijasan (2011) found that inter-bank call rate, Monetary Policy Rate (MPR) and inflation were the major principal components influencing real estate investment. There is also a consensus that the stock market (equities) suffers from lower performance as inflation rises (Bruegeman, Chen \& Thibodeau, 1992; Bello, 2000) and this suggests that real estate equities like REITs will not be an exception. A study conducted in Nigeria by Ajide (2014) investigated the nation's economic growth in the face of capital formation and population. GDP was used as a proxy for economic growth, while the factors of capital formation include Foreign Direct Investment (FDI) and Economic Freedom (EF).

Other economic factors of concern in this study are regarded as MMIs under the regulation of the country's monetary policy as dictated by the CBN. These factors are central to both debt and equity finance of capital projects like REITs. Rigobon and Sack (2004) and Bernanke and Kuttner (2005) revealed that the sharp response of asset prices, and REITs in particular, to the fluctuations of money market components gives serious cause for concern for investors, analysts and policymakers. Bredin, O'Reilly and Stevenson (2006) opined that changes in aggregate monetary policy have an significant impact on general economic activity. The rate of changes in monetary policy tends to influence the value of the underlying portfolio and the rental income of property either in the direct and indirect real estate investment market.

\section{Global Outlook on REITs}

The signing of the REIT Act into Law by the $34^{\text {th }}$ President of the United States, Dwight Eisenhower, in 1960 marks a significant turn of event in the history of REITs (Ong et al., 2011) leading to the creation of the first REIT in 1961 and its subsequent listing on the New York Stock Exchange (NYSE) in 1965 (Ling, Naranjo \& Ryagaert, 2000). Following the creation of the USREIT, different countries across the globe have established REIT regimes at one time or another, resulting in a global REIT market. Currently there are 1 044 REITs in 30 countries around the world. The global REIT capitalisation is $€ 1.51 \mathrm{tn}(\$ 1.78 \mathrm{tn})$ as shown in Table 1 . The average global REITs return is 
$5.1 \%$. REITs in the developed market account for 55\% of listed capitalised stock, but only $7.2 \%$ in developing markets (EPRA, 2018).

Table 1: Continental Outlook of Global REITs and their Ranking

\begin{tabular}{|l|c|c|c|c|}
\hline \multicolumn{1}{|c|}{ Continent } & $\begin{array}{c}\text { No. of } \\
\text { REITs }\end{array}$ & $\begin{array}{c}\text { Capitalisation } \\
\text { (€'billion) }\end{array}$ & $\begin{array}{c}\text { Global } \\
\text { Market } \\
\text { Share (\%) }\end{array}$ & Rank/Position \\
\hline $\begin{array}{l}\text { North America } \\
\text { (USA\& Canada) }\end{array}$ & 247 & 985.702 & 65.27 & 1 \\
\hline Asia Pacific & 249 & 274.50 & 18.18 & 2 \\
\hline Europe & 209 & 197.12 & 13.05 & 3 \\
\hline $\begin{array}{l}\text { South America (Brazil } \\
\text { \& Mexico) }\end{array}$ & 274 & 25.64 & 1.70 & 4 \\
\hline Africa- South Africa & 31 & 21.372 & 1.42 & 5 \\
\hline Middle East & 34 & $\mathbf{5 . 7 7}$ & 0.38 & 6 \\
\hline Total & $\mathbf{1 0 4 4}$ & $\begin{array}{c}\mathbf{1 5 1 0 ~ 1 0 4} \\
\text { (US\$1,780bn) }\end{array}$ & $\mathbf{1 0 0}$ & \\
\hline
\end{tabular}

Source: Authors' compilation from EPRA Global REIT Survey, 2018

\subsection{Importance of Nigeria REITs Market}

With a population estimated at 193392517 people (NBS, 2018) and being the African largest economy, Nigeria is increasingly becoming competitive in the African business environment as noticeable improvements in transparency are gradually being exhibited in the Sub-Sahara African real estate market. Nigeria's real estate market has moved from its opaque low transparency zone and is now ranked 67 out of 100 countries, ahead of Ghana and Rwanda. Lagos city is ranked 124 out of 158 cities ahead of Accra and Kigali for cities considered as regional hubs of attraction for international commercial property investments in Africa (JLL, 2018). On the subject of ease of doing business, Nigeria is now ranked 146 out of 190 nations and the Transparency International Corruption Index placed the country in $148^{\text {th }}$ position out of 180 countries in consideration.

Although these are not the rankings one would expect from Africa's largest economy, they are marked improvements from the nation's 2014 rankings. As a potential real estate investors' destination, the Nigerian real estate market was ranked $40^{\text {th }}$ in term of size. The REIT industry in Nigeria falls within the construction/real estate subsector of the Nigerian Stock Exchange with three REITs (Skye Shelter Fund Plc, Union Homes REIT and UPDC REIT); one property company (UACN Property Development CompanyUPDC Plc); and five construction companies (ARBICO Plc, Costain West Africa Plc, G. Cappa Plc, Julius Berger Plc, Roads Nigeria Plc) listed in the Nigerian Stock Exchange (NSE).

The REIT sector has a total capitalization of NGN37.21bn (US\$ 101.89 million) as at 2018 , representing $0.33 \%$ of the stock market capitalization. Nigeria has three REIT companies having investment in both commercial and residential property sectors but predominantly in medium and high-income housing (Table 2). 
Table 2: Nigeria REIT Profile as at $31^{\text {st }}$ August, 2018

\begin{tabular}{|l|c|c|c|c|c|c|}
\hline \multicolumn{1}{|c|}{ REIT } & $\begin{array}{c}\text { Year } \\
\text { Listed }\end{array}$ & Units & $\begin{array}{c}\text { Price } \\
\text { (NGN) }\end{array}$ & $\begin{array}{c}\text { Capitalisation } \\
\text { (NGN in } \\
\text { millions) }\end{array}$ & $\begin{array}{c}\text { Sector } \\
\text { Share } \\
\mathbf{( \% )}\end{array}$ & $\begin{array}{c}\text { Property } \\
\text { Types }\end{array}$ \\
\hline Skye Shelter & 2007 & 20000000 & 100 & 1900 & 5.37 & $\begin{array}{c}\text { Residential } \\
\text { and } \\
\text { Commercial }\end{array}$ \\
\hline Union Homes & 2008 & 250000000 & 45.22 & 11301 & 30.38 & $\begin{array}{c}\text { Residential } \\
\text { and } \\
\text { Commercial }\end{array}$ \\
\hline UPDC & 2013 & 2668269500 & 9 & 24014 & 64.25 & $\begin{array}{c}\text { Residential, } \\
\text { Commercial } \\
\text { and Hotel }\end{array}$ \\
\hline $\begin{array}{l}\text { Total } \\
\text { Capitalisation }\end{array}$ & & & & $\begin{array}{c}\mathbf{3 7 2 1 6} \\
\mathbf{( \$ 1 0 1 . 8 9 m )}\end{array}$ & \\
\hline $\begin{array}{l}\text { NSE } \\
\text { Capitalisation }\end{array}$ & & & & $\begin{array}{c}\mathbf{1 1 2 5 5 4 5 5 . 2 3} \\
\mathbf{( \$ 3 0 , 8 2 9 . 1 2 )}\end{array}$ & & \\
\hline
\end{tabular}

Source: Authors' Compilation from the Nigerian Stock Exchange Daily Trading data

\section{Literature Review}

In Nigeria, empirical studies have shown that the performance of the real estate investment market is sensitive to the nation's economic outlook and this, by extension, may be applicable to many developing countries (Nzalu, 2013; Ojetunde, 2013; Oyewole \& Ajayi, 2014; Dabara, 2015). Whereas Pham (2013) had described the REIT market as being a thriving venture in the global market. Other authors, including Hardin and Hill (2008); Hamzah and Rozali (2010); Ong, The and Chong (2011); Newell, Adair, \& Nguyen (2013), have corroborated this in their outlined analysis of REIT performance, its associated benefits and inter-relationship with capital, stock and general investment market, especially in the emerging Nigeria REITs market, which is yet to be investigated. In Asia, Newell and Osmadi (2009) and Rozman, et al. (2015) appraised the performance of REITs either as a market-mix asset or property portfolio and they concluded that REITs stand out as superior property investment vehicles. In a study of REIT characteristics and REIT return, Goebel et al. (2013) found that interest rates heavily influenced REIT returns, but size (capitalisation) did not have a strong association with REIT's returns. Asteriou and Begiazi, however, found the magnitude and market maturity of real estates as significant factors influencing REIT's returns. Other studies have also assessed the relationship between the economic variables and the equity market. Firth (1979) found that capital market investments possess an effective hedge against inflation. Fama and Gibbons (1982), and Marshall (1992) reported that investors have shifted attention from cash deposit investments to the equities market in order to benefit from the inflation hedge capacity of stock and bond investments.

The sensitivity of REIT returns to the maturity rate of short and long-term Treasury bills was documented by Swanson, Theis and Casey, (2002) in their study of REIT risk premium sensitivity and interest rates. The study by Islam (2003) found that macroeconomic variables have a statistically significant relationship with stock exchange returns with REITs presenting a better 
diversification to common stock (Bhuyan et al., 2015). In a regression study of equity, REIT returns with secondary market return, Kryzanowski and Tcherednitchenko (2007) reported REITs showing more sensitivity to interest rates ahead of other factors of the market in Canada. This result was corroborated by Nittayagasetwat and Buranasiri (2012) in the US capital market and the study showed that REIT returns was insignificantly sensitive to bond and stock information.

Quite a number of studies have examined the impact, relationship and effects of monetary policy and its instruments/tools on stock, real estate sector and REIT returns, under the broad macroeconomic variables of which monetary policy is a subset. Bredin, O'Reilly and Stevenson (2011) for example, assessed the effect of drastic changes in US monetary policy on REITs, using future market to decompose unexpected changes in policy rates. REITs were found to have a significant negative response to changes in monetary policy. The US monetary policy consistently impacted on REIT returns with dividend showing the manifestation of these influences. In a recent study, Yan (2019) appraised the mechanism of monetary policy on real estate development and real estate prices. The study identified money supply and interest rates as instruments of monetary policy and found that an increase in interest rates increases the cost of real estate development, leading to higher prices and discouraging mortgage institutions to lend to home buyers, which in turn results in a lower performance of the real estate sector. The study limits itself to two of the numerous instruments of monetary policy, exerting influences on the market simultaneously. Interest rates and credit to the corporate sector were also found to be the most influencing variables on house prices in China by Cai and Wang (2018). In the view of Fatnassi et al. (2014), monetary policy instruments are ordinarily expected to affect REIT returns with expansionary policy having an impact in the boom, while the possibility of remaining in the bust market decreases with increases in inflation.

Adopting an Auto Regressive Distributed Lag (ARDL) bound test, (Fang et al., 2016) found a long-run equilibrium exists between REIT's index and interest rates, inflation and stock markets for China and Singapore. The Granger Causality (G-Causality) test shows an unidirectional relationship in Japan and Singapore indicating that a shift in interest rates results in changes in REIT indices. Tsai (2015) examined the dynamism between the US real estate and stock markets and found a short-term causal relationship, but no trace of a long-term relationship. Bernhard (2017) investigated the effect of non-traditional monetary policies on Swiss asset prices and reported a great impact on long-term government bonds (7-10 years), while the expansionary monetary policies reduced yield from both government and corporate bonds in Switzerland. Expansionary monetary policies promote the Swiss currency (Swiss Franc) appreciation, but devastate stock prices.

In a study of the relationship between commercial real estate return and economic, fiscal and monetary factors and inflation in US and UK, Hoesli et al. (2008) found a negative relationship of real estate return with inflation, both anticipated and unexpected, while assets (stocks) portrayed a long-run 
positive relationship with inflation. Muller and Pauley (1995) found a low correlation of REIT prices and interest rates exhibiting a stronger negative correlation in a falling environment and minor negative correlation during rising interest rates. The study called for further research to ascertain REIT price movement predictors such as GDP, inflation and employment. Crossland (2007) observed the sensitivity of Australian Listed Property Trusts (LPT) to interest rate dynamics. The results shows a weak negative (inverse) relationship to short-term interest rates and a stronger inverse relationship to long-term interest rate fluctuations, therefore indicating a high debt ration contributing to the negative effect. Yunus (2012) studied securitised property markets, stock markets and macroeconomic factors for developed countries and found that co-integration amongst the variable stocks of the stock market, GDP, money supply and inflation, caused a positive effect in property returns, whilst interest rates recorded a negative impact on property returns. A low frequency but a strong and positive association was reported to have existed between macroeconomic risks and real estate securities volatility (Lee, Stevenson \& Lee, 2018).

In Nigeria, the study of the effect of monetary policy variables focus on economic growth in terms of GDP. Adegbite and Alabi (2013) studied the relationship between monetary policy and economic growth in Nigeria. The variables considered were money supply, inflation, exchange rate, interest ratea and GDP, with the data spanning from 1970 to 2010. The study found the variables to have had a significant effect on economic growth and reported a stable exchange rate keeping inflation low, while the interest rate influences the economic activity and prices. The money supply and prices were found to be stable and predictable. The study adopted Ordinary Least Squares (OLS) regression model and made money supply to be independent rather than the GDP which is a better measure of growth. The results showed that money supply was $61 \%$ dependent on the predictor variables. Contrarily, Ekwe, Ogbonnaya and Omodero (2017) represented economic growth with GDP as the dependent variable on the monetary policy instruments of BMS and Credit to Private Sector (CPS). The study found no significant impact of monetary policy on the Nigerian economy represented by its GDP. This indicates improper regulation of BMS tools resulting in a high rate of lending to the corporate sector. A distinct fundamental observation between the studies of Adegbite and Alabi (2013) and Ekwe et al. (2017) is that BMS is the measure of economic growth and dependent variable in the former, while GDP is the dependent variable in the latter.

Onyeiwu (2012) found a significant direct impact of money supply on GDP using OLS method for a dataset ranging from 1981 to 2008. Udude (2014), employing an Augmented Dickey-Fuller (ADF) Unit Root Test and Johansen Co-integration test with VECM, found a non-significant impact of money supply on the GDP (economic growth). Abdulazeez (2016) reported a marginal impact of all economic growth indices on GDP, including money supply. Nwoko, Iheneje and Anumadu (2016) also found money supply to have no influence on GDP. The CPS effect was investigated in relation to interest rates and inflation by Ngerebo-A (2016) who found CPS to be significant to changes in the inflation rate. The study used inflation as a proxy 
for the economy. Oluwofeso, Adeleke and Udoji (2015) adopted the Cointegration Test earlier and found a significant impact of CPS on GDP. Ayodeji and Oluwole (2018) in their study of the impact of monetary policy on economic growth in Nigeria, proxied monetary policy variables with money supply, interest rates, exchange rates and liquidity ratio to predict economic growth represented with GDP. Their study found money supply and exchange rates to have a positive but fairly significant impact on GDP. Other factors exhibited a significant negative impact on economic growth. The study adopted ADF Unit Root Test, Johansen Co-integration test and VECM from data for the period of 1981 to 2016.

Victoria et al. (2016) used multiple linear regression analysis to investgate monetary policy's effectiveness on Nigerian economic development, where the predictor variables (exchange rate, interest rate, inflation and money supply) significantly impact on GDP. Using a data span of 1981 to 2015, an investigation of the impact of fiscal and monetary policies was carried out by Bodunrin (2016), the study found the monetary policy tool of money supply, exchange rates and taxes to have a negative permanent effect on growth. The study adopted VAR and GSM. Ufoeze et al. (2018), in their study of monetary policy's effect on Nigerian economic growth, used variables like money supply, exchange rates, lending rates and investment as predictor variables. Using OLS, Unit Root Test and Co-integration Test, the results show a longrun relationship among the variables with only money supply having a significant positive impact on economic growth (GDP). Nzomoi and Rutto (2012) studied the effect of CPS on economic performance represented with GDP in Kenya using panel data analysis and found a significant positive influence of CPS on economic performance. Olaleye, Bello and Ayodele (2015) examined the determinants of the listed property stock prices in Nigeria, where the macroeconomic factors considered in the study include GDP, Consumer Price Index (CPI), Gross National Product (GNP) (as GDP deflator), inflation, interest rates, unemployment and exchange rates. Nigeria REITs were excluded from the study as the listed property sector was represented by the only listed property development company in Nigeria (the UACN property development company) at the time of their study. The results showed that interest rates and inflation are inversely related to property stock price. Despite the available literature on monetary policy of the $\mathrm{CBN}$, the focus was on economic development proxies by GDP or inflation or money supply. The available study of these instruments on REITs focused on index return, market prices or real estate pricing. No study to the best of our knowledge has investigated these monetary policy instruments on the Nigerian REITs market and on REIT dividend returns. The result of the existing studies also did not point to a consensus as contradicting views have been reported. This study therefore considers the MMIs as variables of interest towards REIT dividend performance having observed that no similar investigation has been carried out in Nigeria despite the 13 years of REIT establishment in the country. The focus therefore is the analyses of the causal relation between the N-REIT and MMIs. 


\section{Methodology}

\subsection{Data Description}

The study used Sky Shelter REIT (SKY REIT) (equity) as a proxy for REIT dividend returns. The selection of Sky Shelter REIT was based on the fact that the REIT was the first of its type to be launched on the NSE in 2007. Also, the REIT have since inception been consistently publishing its annual financial statements. In order to avoid data distortion for the study period (2008-2017), other REITs in operation in Nigeria, including UnionHome and UPDC REIT, established in 2010 and 2013 respectively, were excluded from this study based on their short period of existence and the inconsistency in the availability of their annual financial statements. Thus, SKY REIT's data was converted into quarterly data prior to analyses so as to ensure data uniformity with the exogenous data.

The datasets for this study are time series data of Skye REIT dividend returns (SKY REIT) (see Table 3) as a dependent variable and the selected variables of the money market regarded as MMIs comprising 5 predictor elements: The existing literature, such as Simo-Kengne (2015), Lee and Lee (2014), Fatnassi et al. (2014), Yunus (2012) and Bredin et al (2010) have identified instruments of monetary/macroeconomic policy, to include BMS (BMS) usually regarded as money supply or $\mathrm{M}_{2}$. PLR is the same as interest rate; CPS, as used in other literature; CIC and TBR are the monetary policy variables. Only interest rates and money supply had featured more in literature and this study felt other less researched variables equally have influences on investment return and were worth consideration.

The quarterly data of the predictor variables were extracted from the published statistical bulletin of the CBN and NBS for the period 2008 to 2017. The study deployed Skewness, Kurtosis and Jarque-Bera for Normality Test; Multicollinearity Test; Johansen Co-integration Test for time dynamic relationship; and GSM to investigate the relationship.

\subsubsection{Normality of Data Distribution}

Normality Test, as required statistically for regression and econometric analysis of this nature, is conducted to check if the distribution of the datasets is normal. A non-normal distributed data will not be suitable for the GCausality Test. The study deployed Jarque-Bera Test. The test measures the significant difference of the skewness and Kurtosis for the series with those of the normal distribution. The statistic is computed as:

$$
\begin{array}{ll}
\text { Skewness (SK) } & E\left(R_{i, t}-\mu\right)^{3} / \sigma^{3} \ldots \ldots \ldots \ldots \ldots(i) \\
\text { Kurtosis (KUR) } & E\left(R_{i, t}-\mu\right)^{4} / \sigma^{4} \ldots \ldots \ldots \ldots \ldots \ldots(i i)
\end{array}
$$

Where $\boldsymbol{\mu}$ is the mean and $\boldsymbol{\sigma}$ is the Standard Deviation

$$
\text { Jarque-Bera Test } T\left(S K^{2} / 6+(K U R-3)^{2} / 24\right.
$$




\subsubsection{Data Screening and Model Fitness}

To ensure the reliability of the independent variables (MMIs) employed in the prediction of variable explained (REIT dividend returns), the study conducted a model fitness test for the dataset. The tests are Unit Root Test, Multicollinearity Test, and Lag Length Criteria Selection Test. Dickey and Fuller, (1979) expressed the hypothesis testing in Augmented Dickey-Fuller Test statistic (ADF) model as:

$$
Y_{t}=\alpha Y_{t-1}+X_{t} \delta+\epsilon_{t}
$$

\subsection{Cause-effect Relationship Methods}

There are different econometric analyses that had been adopted in literature to analyse influences and causal relationship of interactions between variables. Nittayagasetwat and Buranasiri (2012) used CIR model to check sensitivity of bond coupon (return) to stock market (index) return; Fei, Ding and Dang (2008) adopted a Multivariate Generalized Autoregressive Conditional Heteroskedasticity (MGARCH) model in their work; Ma' in et al. (2015) and Kryzonowski and Tcherednitvhenko (2007) employed a regression model to estimate the relationship between variables of interest in their studies. The current study adopted GSM because it is regarded as a reliable econometric model to establish the form of the relationship between MMIs and equity REIT returns in Nigeria. The adoption of G-Causality, developed by Granger (1969), was recommended in the work of Asghar and Abid (2007). A number of similar studies have adopted the ADF Unit Root Test of stationarity of data, Ganger Causality Test, ARDL, VAR and VECM in their investigations (Udude, 2014; Tsai, 2015; Bodunrin, 2016; Fang et al., 2016; Ayodeji \& Oluwole, 2018; Ufoeze et al., 2018; Yan, 2019). The GCausality Test also shows the statistical significance of each factor and the combined effect of all factors/indicators following a series of statistical tests to confirm the data fitness to model for a reliable prediction.

\subsubsection{Granger Causality Model (GSM)}

The development of GSM emerged out of an idea conceptualised by Norbert Wiener (Wiener, 1956). The model explains the interactive relationship between two stationary data series. Granger (1969) and Bressler and Seth (2010) posited that, the need for a practical approach to cause-effect dependency among variables of interest birthed the GSM. Bressler and Seth (2010) explain the GSM as a situation of having two variables $A$ and $B$, in an attempt to predict $A_{t+l}$ using only past terms of $A$. In this study, we attempt to predict $A_{t+1}$ using past terms of both $A$ and $B$. If the second prediction is significantly more successful, then the past term of $B$ contains information useful for predicting $A_{t+1}$, that is not in the past. In this case, $B$ is said to Granger-Cause $A$. Thus, the generalised GSM is expressed as:

Given two stationary time series $\mathrm{X}=\left\{\mathrm{X}_{(\mathrm{t})}\right\}_{\mathrm{teZ}}$, and $\mathrm{Y}=\left\{\mathrm{Y}_{(\mathrm{t})}\right\}_{\mathrm{t} \in \mathrm{Z}}$ with the following information sets: 
(i) $\mathrm{I}^{*}(\mathrm{t})$, the set of all information in the universe up to time $t$, and

(ii) $\mathrm{I}^{*}-\mathrm{X}_{(\mathrm{t})}$, the set of all information in the universe excluding $X$ up to time $t$.

$X$ is defined to Granger cause $\mathrm{Y}$ if $\mathrm{P}\left[\mathrm{Y}_{(\mathrm{t}+1)} \in \mathrm{A}\left[\mathrm{I}^{*}(\mathrm{t})\right] \neq \mathrm{P}\left[\mathrm{Y}_{(\mathrm{t}+1)} \in \mathrm{A}\left[\mathrm{I}^{*} \mathrm{X}_{(\mathrm{t})}\right]\right.\right.$ Where:

$Y$ represents the Equity REIT Dividend Yield Returns (in Unit)

$X$ represents the Money Market Indicators which comprises of:

Currency in Circulation (CIC: \% change)

Corporate Private Sector (CPS: \% change)

Prime Lending Rate (PLR: \% change)

Treasury Bill Rate (TBR: \% change)

Broad Money Supply (BMS: \% change)

Therefore, Vector Error Correction Model (VECM) model for multiple time series $\mathrm{X}_{1}, \ldots, \mathrm{X}_{\mathrm{V}}$, for each time series $\mathrm{X}_{\mathrm{j}}$, is given as:

$$
\mathrm{Xj}(t)=\sum_{\mathrm{i}=1}^{\mathrm{V}} \beta \mathrm{j}, \mathrm{X}_{\mathrm{i}}^{\mathrm{t}, \text { Lagged }}+\epsilon_{\mathrm{i}}(\mathrm{t})
$$

where $\mathrm{X}_{\mathrm{i}}^{\mathrm{t}}$,Lagged $=[\mathrm{Xi}(\mathrm{t}-\mathrm{L}), \ldots \ldots, \mathrm{Xi}(\mathrm{t}-1)]$ is the history of $\mathrm{Xi}$ up to time $\mathrm{t}, \mathrm{L}$ is the maximal time lag, and $\beta \mathrm{j}, ; \mathrm{i}=[\beta \mathrm{j} ; \mathrm{i}(1), \ldots \ldots, \beta \mathrm{j} ; \mathrm{i}(\mathrm{L})]$ is the vector of coefficients modelling the effect of time series $\mathrm{Xi}$ on the target time series (Granger, 1969; Engle \& Granger, 1987).

\subsection{Co-integration of REIT's Dividend Returns and MMIs}

Co-integration Test shows the forms (short or long) of the relationship existing between the variables. The study deployed Johansen Co-integration Test to conduct time dynamic relationships between the dependent and independent variables. Johansen Co-integration Test conducts two tests: Trace Statistics and Max-Eigen Statistics. They are computed as follows ((Johansen, 1985)

\section{Trace Rank Test}

$$
\Delta R E_{t}=\gamma_{1}+\sum_{i=1}^{n} \varphi_{1} \Delta R E_{t-i}+\sum_{i=1}^{n} \tau_{1} \Delta X_{t-i}+\delta_{1}\left(R E_{t-1}-\beta X_{t-1}-\alpha\right)+\varepsilon_{3 t} \ldots(v i)
$$

\section{Max-Eigen Ranks Test}

$\Delta X_{t}=\gamma_{2}+\sum_{i=1}^{n} \varphi_{2} \Delta R E_{t-i}+\sum_{i=1}^{n} \tau_{2} \Delta X_{t-i}+\delta_{2}\left(R E_{t-1}-\beta X_{t-1}-\alpha\right)+\varepsilon_{4 t} \ldots \ldots(v i i)$

\section{Results}

The analysis performed on the data involved the data normality screening and Unit Root Test, followed by Multicollinearity and Co-integration Test. The 
G-Causality relationship analysis was performed to establish the causal relationship between the predictor variables and REIT returns. The result of the analysis is presented in the following sections in return.

\subsection{Result of Statistical Analysis and Tests}

The summary of test and analysis for Normality ADF-Unit Root Test, Vector Auto Regression and Vector Error Correction is presented in Table 3. Descriptive statistics of the normality test show that, SKR and TBR were negatively skewed having -0.2315 and -0.2745 values respectively. These imply that more of the values in the SKR and TBR datasets are lower than their mean value. On the other hand, indicators such as BMS, CIC, CPS and PLR are positively skewed showing the dataset to have more values higher than their mean values. However, the values of negative or positive skewness associated with the dataset were within the critical region of normality $( \pm 1.96)$, which indicates that the dataset passes the Normality Test required for this analysis.

Kurtosis measures the sharpness of the peak or flatness of the series distribution. All the data series exhibited leptokurtic nature of data distribution around the mean value with the peak above the normal distribution curve. Jarque-Bera Statistical Test for the dataset confirmed the normal distribution of the data over the study period having the calculated values for all the variables lower than the critical value (5.99) for a small sample size and the insignificant probability values $(p>0.05)$.

Table 3: Summary of Tests and Analysis (Normality, ADF, VAR \& VEC)

\begin{tabular}{|c|c|c|c|c|c|c|c|c|c|}
\hline \multirow[b]{2}{*}{ MMI } & \multicolumn{3}{|c|}{ Normality Test } & \multicolumn{2}{|c|}{ ADF-URT } & \multicolumn{2}{|c|}{ VAR } & \multicolumn{2}{|c|}{ VECM } \\
\hline & 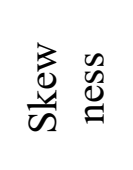 & 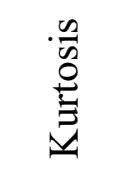 & 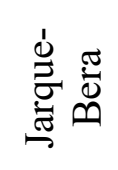 & d & & $\frac{3}{d} \underset{d}{d}$ & $\frac{n}{\sqrt[n]{0}}$ & 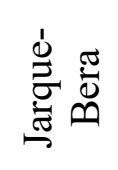 & d \\
\hline CIC & 0.1156 & 2.4043 & 0.6125 & -0.2099 & CIC & 56 & 2.4043 & 0.6125 & -0.2099 \\
\hline CPS & 0.0544 & & 1.9751 & -0.4374 & CPS & 0.0544 & 1.8577 & 1.9751 & -0.4374 \\
\hline PLR & 0.6720 & 3.2330 & 2.7917 & $-3.9472 *$ & PLR & 0.6720 & 3.2330 & 2.7917 & $-3.9472 *$ \\
\hline TBR & -0.2745 & 2.1806 & 1.4592 & -1.5110 & TBR & -0.2745 & 2.1806 & 1.4592 & -1.5110 \\
\hline BMS & 0.2856 & 1.9600 & 2.1120 & 0.7153 & BMS & 0.2856 & 1.9600 & 2.1120 & 0.7153 \\
\hline Skye & -0.2315 & 1.7700 & 2.5189 & & Skye & -0.2315 & 1.7700 & 2.5189 & \\
\hline \multicolumn{6}{|c|}{ Adjusted $\mathrm{R}^{2}$} & \multicolumn{2}{|c|}{$0.955620(95.56 \%)$} & \multicolumn{2}{|c|}{$0.543928(54.39 \%)$} \\
\hline
\end{tabular}

*VAR and VECM Significant at $P<0.05$

The Augmented Dickey-Fuller test statistic (ADF t-statistic) Unit Root Test (Table 3 ) revealed that PLR is significant at both levels (I0) and $1^{\text {st }}$ difference with t-statistics value of (-3.9472 and -4.6019) respectively, less than critical value $(-2.9484)$ confirming the stationarity of the predictor- PLR. Other predictor variables are stationary at $1^{\text {st }}$ difference with their t-statistics ($4.7099,-4.7010,-4.7652$ and -6.0667 respectively) lower than the critical value of -2.9511 which further strengthens the data stationarity. 


\subsection{Multicollinearity}

The Multicollinearity Test (Table 4) showed that, the highest (absolute) correlation coefficient among the independent variables (MMIs) is 0.8224 (82.24\%), which exists between BMS and CIC. The correlation co-efficient is lower than the cut off value of $0.9(90 \%)$ or greater value. This implies that the independent variables have no serial correlation problem that can adversely affect prediction and reliability. The dataset of the indicators (explanatory variables) passed the Multicollinearity and Unit Root Tests and are suitable for further analysis of the causal relation.

Table 4: Multicollinearity Test of Independent Variables (MMIs)

\begin{tabular}{cccccc}
\hline & $\mathbf{X}_{\mathbf{1}}$ & $\mathbf{X}_{\mathbf{2}}$ & $\mathbf{X}_{\mathbf{3}}$ & $\mathbf{X}_{\mathbf{4}}$ & $\mathbf{X}_{\mathbf{5}}$ \\
\hline $\mathbf{X}_{\mathbf{1}}$ & 1.0000 & & & & \\
$\mathbf{X}_{\mathbf{2}}$ & 0.8224 & 1.0000 & & & \\
$\mathbf{X}_{\mathbf{3}}$ & 0.7771 & 0.7989 & 1.0000 & & \\
$\mathbf{X}_{\mathbf{4}}$ & -0.1097 & -0.1796 & -0.0462 & 1.0000 & \\
$\mathbf{X}_{\mathbf{5}}$ & 0.4717 & 0.5645 & 0.5512 & -0.4239 & 1.0000 \\
\hline
\end{tabular}

$X_{I}:$ BMS; $X_{2}: C I C ; X_{3}: C P S ; X_{4}: P L R ; X_{5}: T B R$

Sever correlation at $\geq 90 \%$

\subsection{Cointegration Test}

Table 5 presented the time dynamic relationship of REIT dividend returns and MMIS. The Trace statistics (t-stats) showed that, at most, three cointegrations exist among REIT dividend returns and MMIS, having the hypothesised: None*, at most $1^{*}$ and at most $2 *$, with their t-stats of $120.8278,72.64862$ and 50.18463 and p-values $(0.0003,0.0292$ and 0.0297$)$ respectively showing significance at $\mathrm{p}<0.05$.

The results indicate the existence of a co-integration between REIT dividend returns and MMIs. Trace Rank Test (at most 4 and at most 5) is insignificant, indicating no presence of co-integration.

Complementary analysis of Max-Eigen statistics showed that, at most, one co-integration exists among REIT dividend returns and MMIs. The hypothesized None* Max-Eigen value of 48.17914 being more than the critical value of 40.07757 with a significant probability value $(\mathrm{p}=0.005)$ indicating the presence of co-integration. The Johansen Co-integration Test of Trace and Max-Eigen statistics conducted confirmed both long and shortrun relationships exist between REIT dividend returns and MMIs. 
Table 5: Johansen co-integration test

\begin{tabular}{|l|c|c|c|c|c|c|}
\hline \multirow{2}{*}{$\begin{array}{l}\text { Hypothesized } \\
\text { No. of CE(s) }\end{array}$} & \multicolumn{3}{|c|}{ Trace Rank Test } & \multicolumn{3}{c|}{ Maxi-Eigen Rank Test } \\
\cline { 2 - 7 } & t-Stats & $\begin{array}{c}\text { CV } \\
(\mathbf{0 . 0 5})\end{array}$ & $\begin{array}{c}\text { P- } \\
\text { Value }\end{array}$ & $\begin{array}{c}\text { M-E } \\
\text { Stats }\end{array}$ & $\begin{array}{c}\text { CV } \\
(\mathbf{0 . 0 5})\end{array}$ & $\begin{array}{c}\text { P- } \\
\text { Value }\end{array}$ \\
\hline None & 120.8278 & 95.75366 & 0.0003 & 48.17914 & 40.07757 & 0.0050 \\
At most 1 & 72.64862 & 69.81889 & 0.0292 & 22.46399 & 33.87687 & 0.5717 \\
At most 2 & 50.18463 & 47.85613 & 0.0297 & 21.33066 & 27.58434 & 0.2567 \\
At most 3 & 28.85397 & 29.79707 & 0.0639 & 17.51178 & 21.13162 & 0.1492 \\
At most 4 & 11.34219 & 15.49471 & 0.1913 & 11.26784 & 14.26460 & 0.1413 \\
At most 5 & 0.074343 & 3.841466 & 0.7851 & 0.074343 & 3.841466 & 0.7851 \\
\hline
\end{tabular}

\subsection{Causality Relationship of REIT Dividend Returns and MMIS}

The predictive power of G-Causality largely depends on, and influenced by, lag length structure (Asghar \& Abid, 2007). Schwarz (1978) expressed the Schwarz Information Criterion (SIC) lag length selection criterion as follows:

$$
\mathrm{SIC}=n \operatorname{In}\left(\sigma^{2}\right)+n^{-1} p \operatorname{In}(n)
$$

Predictions of GSM for short and long-term relationship were conducted using VAR model and VECM (Table 3). For short-run analysis, MMIs such as TBR, PLR and CPS (with $\mathrm{p}<0.05$ Granger) cause N-REIT dividend returns while CIC and BMS (having $\mathrm{p}>0.055$ ) do not Granger cause N-REIT dividend returns in the VAR model. The result of VAR indicates that TBR, PLR and injection to CPS have statistically significant explanatory power to the prediction of the variance in the N-REIT's dividend returns. VECM model for long-run analysis (Tables 3 ) suggests only PLR can Granger cause $\mathrm{N}$-REIT dividend returns, this being the only indicator with a significant $\mathrm{p}$ value (0.03) in a long-run relationship.

\section{Discussion of Findings}

This paper studied the relationship, direction and significance of the effect of monetary policy instruments (regarded as Money Market Indicators- MMIs) on the Nigeria REIT's dividend return. The data for this study exhibited normality of distribution. The dataset for all variables passed Unit Root Test (ADF) confirming stationarity. There is no multicollinearity in the dataset (free from serial correlation) making the data suitable for the method adopted. The results show that the instruments of Nigerian monetary policy considered in this study had a short-term relationship with REIT dividend returns, and by extension, with performance and growth. The findings of a short-term relationship in this study corroborate the study of Tsai (2015) who reported a similar finding of a short-term relationship. The current study however found a long-term relationship of PLR with REIT returns; showing that PLR had both short-run and long-run effects on REIT returns. This is in agreement with results of Ufoeze et al. (2018), Bernhard and Ebner (2017) and Fang et al. (2016) that interest rate possessed a long-term relationship with economic growth. 
The results further show that only three indicators; PLR, CPS and TBR have a significant effect on REIT yields, but in different directions. PLR was significant both with the VAR and VECM but with negative estimates. This implies that the regime of lending rate over the years has not been favourable to the REIT market. This finding aligns with Swanson et al. (2002), Yunus (2012), Olaleye et al. (2015); Bodunrin (2016) and Ayodeji and Oluwole (2018). The outstanding effect of PLR both in the short and long-runs on REIT dividend returns also echoed the results of Kryzanowski and Tcherednitchenko (2007) and Ma'in et al (2016); that REITs are sensitive to interest rates but with insignificant effect, as reported by: Adegbite and Alabi (2013), Cai and Wang (2018), Ufoeze et al. (2018), and Yan (2019). The findings further show CPS as having a significant negative relationship; suggesting an inadequacy of the credit to the corporate sector. This is not surprising as it supports the PLR relationship. It is obvious that financing projects or businesses, including real estate development, is difficult in Nigeria where interest rates are high. This result contradicts earlier findings of a positive CPS relationship to growth (Were et al., 2012; Cai \& Wang, 2018). Ngerebo-A (2016) and Oluwofeso et al. (2015) did not indicate the direction of the significant relationship of CPS found in their study. However, the result is in opposition to Ekwe et al. (2017) who found no significant relationship of CPS to economic development. TBR also shows a significant relationship to REIT returns and is unexpectedly positive in nature. This finding suggests an increase in TBR will lead to an increase in REIT dividend returns.

BMS and CIC have no significant relationship with REIT returns. CIC is considered a part of BMS and it is not surprising that both go the same way having insignificant positive relationships with REIT returns in the short-run. This finding is supported by Yunus (2012); Udude (2014); Abdulazeez (2016); Nwoko et al. (2016); Ekwe et al. (2017); and Ayodeji and Oluwole (2018), who reported a fairly significant relationship. The current study disagrees with Victorial et al. (2016), Onyeiwu (2012), and Yan (2019), who found BMS as having a significant impact on economic development in Nigeria. Again, the CIC in the long-run exhibits a negative influence, indicating that at a point an increase in CIC can lead to inflation with its consequential negative effect on investment return. Although this is insignificant in contrast to inflation rate, which has a significant effect on REIT returns as reported by Oni et al. (2011) and Ma'in et al. (2016). The finding however agrees with Firth (1979), Fama and Gibbons (1982) and Marshall (1992) where there is no significant inflation effect on REITs. The Johansen co-integration test result by both Trace and Max-Eigen values in Table 3 shows a co-integration (relationship) between REIT returns and MMIs suggesting that MMIs can significantly predict the REIT dividend returns in both the short (PLR, CPS and TBR) and long-run (PLR) respectively.

TBR exhibited a similar finding to bond coupon rate effect on REITs portrayed by Nittayagosetwat and Buranasiri (2012) and supported by Astrious and Bogiazi (2013). In effect, the short-run prediction effect of 
MMIs is significant, while in the long-run only PLR shows a significant prediction.

\section{Conclusion}

This is a pioneering study on the predictive effect of MMIs on REIT dividend returns in Nigeria adopting the Co-integration Test and G-Causality Test. The Johansen Co-integration Test confirmed the existence of a relationship between REIT returns and the MMI variables both in the short-run (through Trace) and long-run (using Max-Eigen values). The Causality Test using VAR analysis indicates that TBR, PLR and CPS Granger Cause the dividend return in the short-run, suggesting a significant prediction power of the factors on REIT dividend returns. The VECM further indicated that only one MMI variable (PLR) has significant predictive power over REIT returns in the long-run. The study concluded that the causal effect of MMIs on REIT dividend returns is more significant in the short-run and less significant (one factor only) in the long-run. Also, PLR is a money indicator of great causal effect on REIT returns and needs greater consideration by property investors and property investment managers. The authors acknowledge the limitation of the small dataset in this study. However, said limitation has not had any devaluing effect on our findings as the dataset passed all the tests for the adoption of the method used and the results are similar to other studies.

\section{References}

Abdulazeez, M.N. (2016). Impact of monetary policy on the economy of Nigeria. Pyrex Journal of Business and Finance Management Research, 2(10) pp.163-179.

Adegbite, T.A. \& Alabi, W.O. (2013). Monetary policy and economic growth: The Nigeria Experience (1970-2010). Prime Journal of Business Administration and Management, 3(1), pp.822-833.

Ajide, K.B. (2014). Determinants of Economic Growth in Nigeria. $C B N$ Journal of Applied Statistics, 5(2), pp.147-170.

Asghar Z. \& Abid I. (2007). Performance of lag length selection criteria in three different situations. Islamabad: Quaid-i-Azam University.

Asteriou, D. \& Begiazi, K. (2013). Modeling of daily REIT returns and volatility. Journal of property Investment and Finance, 31(6), pp.589601.

Ayodeji, A. \& Oluwole, A. (2018). Impact of Monetary Policy on Economic Growth in Nigeria. Open Access Library Journal, 5(2). Doi: 10.4236/0alib.1104320.

Barkham, R. J., Ward, C.W.R. \& Henry, O.T. (1996). The Inflation Hedge Characteristics of UK Property. Journal of Property Finance, 7(1), pp.62-76.

Bello, O.M. (2000). Risk Management in the Process of Property Development Construction in Nigeria. Journal of the Federation of Construction Industry, 15(3), pp.15-23. 
Bello, O.M. (2005). The Inflation Hedging Attributes of Investments in Real Estate, Ordinary Shares and Naira Denominated Deposits between 1996 and 2002. Journal of Banking, 1(1), pp.1-28.

Berhard, S. \& Ebner, T. (2017). Crossborder spill over effectof unconventional monetary policies on Swiss asset prices. Journal of International Money and Finance, 75, pp.109-127.

Bernanke, B.S. \& Kuttner, K.N. (2005). What explains the stock market's reaction to Federal Reserve policy? The Journal of Finance, 60(3), pp.1221-1257.

Bhuyan, R., Kuhle, J., Al-Deehani, M.T. \& Mahmood, M. (2015). Portfolio diversification benefits using real estate investment trusts: An experiment with US common stocks, equity real estate investment trusts, and mortgage real estate investment trusts. International Journal of Economics and Financial, 5(4), pp.922-928.

Bodunrin, O.S. (2016). The Impact of Fiscal and Monetary Policy on Nigerian Economic Growth. MPRA Paper No.92811. Available at: https://mpra.ubs.uni-muenchen.de/92811/

Bredin, D., O’Reilly, G. \& Stevenson, S. (2011). Monetary policy transmission and real estate investment trusts. International Journal of Finance \& Economics, 16(1), pp.92-102.

Bruegeman, W.B., Chen, A.H. \& Thibodeau, T.G. (1992). Some Additional Evidence on the Performance of Commingled Real Estate Investment Funds 1972-1991. Journal of Real Estate Research, 7, pp.433-448.

Cai, W. \& Wang, S. (2018). The Time Varying Effect of Monetary Policy on House Price in China: An Application of TVP-VAR Model with Stochastic Volatility. International Journal of Business Management, 13(4), pp.149-157.

CBN (2016). Monetary Policy. Education in Economic Series, No.2. CBN Research Department.

Crossland, A.J. (2007). Interest rate effects on Listed Property Trust's Performance. A paper presented at the $13^{\text {th }}$ Pacific Rim Real Estate Society's Annual Conference held at Freemantle, West Australia, January 21-24

Dabara, I.D. (2015). The inflation-hedging performance and risk-return characteristics of residential property investments in Gombe, Nigeria. Advances in Research, 3(1), pp.71-83

Daud, S.Z., Mohd, A.H., Sipan, I.A. \& Wilson, A.J. (2012). The Impact of location attributes on REITs' Return. 3rd International Conference on Business and Economic Research Indonesia. pp.311-332.

Ekwe, M.C., Ogbonnaya, A.K. \& Omodero, C.O. (2017). Monetary Policy and Nigeria Economy: An Impact Investigation. International Journal of Economics and Finance, 9(11), pp.218-222.

EPRA (2018). Global REIT Survey. European Public Real Estate Association.

Ezema, C.C. (2009). Monetary Policy Framework in Nigeria: Formulation and Implementation challenges. A paper Presented at African Institute of Applied Economics Monthely Seminar, August.

Fama, E.F. (1981). Stock returns, real activity, inflation, and money. The American Economic Review, 71(4), pp.45-565. 
Fama, E.F. \& M.R. Gibbons (1982). Inflation, real returns, and capital investment. Journal of Monetary Economics, 9, pp.297-323.

Fei, P., Ding, L., and Deng, Y. (2008). Correlation and volatility dynamics in REIT returns: performance and portfolio considerations. Working Paper Series. Singapore: Institute of Real Estate Studies.

Falnassi, I. Slim, C., Ftiti, Z. \& Maatoug, A.B. (2014). Effect of monetary policy on REIT returns: Evidence from the United Kingdom. Research in International Business and Finance, 32, pp.15-26.

Fang, H., Chang, T.Y., Lee, Y.H. \& Chen, W.J. (2016). The Impact of macroeconomics factors on the real estate investment trusts index return on Japan, Singapore and China. Investment Management and Financial Innovation, 13(4), pp.242-253.

Firth, M. (1979). The relationship between stock market returns and rates of inflation. Journal of Finance, 34(3), pp.743-749.

Goebel, P.R., Harrison, D.M., Mercer, J.M. \& Whitby, R.J. (2013). REIT Momemtum and Characteristics-Related REIT Returns. Journal of Real Estate Finance and Economics, 47, pp.564-581.

Hamelink, F. \& Hoesli, M. (1996). Swiss Real Estate as a Hedge against Inflation: Evidence using Hedonic and Auto Regressive Models. Journal of Property Finance, 7(1), pp.33-49.

Granger J.W.G. (1969). Investigating Causal Relations by Econometric Models and Cross-spectral Methods. Econometrica, 37(3), pp.424438.

Hamelink, F., Hoesli, M. \& MacGregor, B. (1997). Inflation Hedging versus inflation protection in the US and Uk. Real Estate Finance, 14(2), pp.63-73.

Hamzah, A.H. \& Rozali, M.B. (2010). Empirical investigation on the performance of the Malaysian real estate investment trusts in precrisis, during crisis and post crisis period. International Journal of Economics and Finance, 2(2), pp.62-69.

Hardin III, W.G. \& Hill, M.D. (2008). REIT Dividend Determinant: Excess Dividends and Capital Markets. Real Estate Economics, 36(2), pp.349-369.

Hoesli, M. Liziei, C. \& MacGregor, B. (2008). The Inflation Hedging Characteristics of US and UK Investments. A Multi Factor Error Correction Approach. Journal of Real Estate Finance and Economics, 36, pp.183-206

Hoesli, M. (1994). Real Estate as a Hedge against Inflation: Learning from the Swiss Case. Journal of Property Valuation and Management, 12(3), pp.51-59.

Hoesli, M., Matysiak, B. \& Nanthakumaran, N. (1996). The long-term Inflation Hedging Characteristics of UK Commercial Property. Journal of Property Finance, 7(1), pp.50-61.

Islam, M. (2003). The Kuala Lumpur Stock Market and Economic Factors: A General-to-Specific Error Correction modeling test. Journal of Academy of Business and Economics, 1(1). Available at: http://jabejournal.org/JABE-JOURNAL/Documents/Abstracts/JABE-11 Abstracts.pdf

JLL. (2018). Global Real Estate Transparency Index. Chicago: Jones Lang LaSalle. 
Kryzanowski, L. \& Tcherednitchenko, M. (2007). Performance of Canadian E-REITs. International Real Estate Review, 10(2), pp.1-22.

Kuttner, N.A. (2001). Monetary Policy Suprises and Interest rates: Evidence from the Federal Funds Futures Markets. Journal of Monetary Economics, 47(3), pp.523-544.

Lee, C.L., Stevenson, S \& Lee, M.L. (2018). Low Frequency Volatility of Real Estate Securities and Macroeconomic risk. Accounting and Finance, 58(1), pp.311-342.

Ling, D.C., Naranjo, A. \& Ryagaert, M.D. (2000). The predictability of Equity REIT Returns: Time Variation and Economic Significamce. Journal of Real Estate Finance and Economics, 20(2), pp.117-136.

Ma'in, M., Arifin, N.A.M., Hatta, M.F.M., Hashim, M.H. \& Isa, S.S.M. (2016). Determinants of Islamic real estate investment trust performance. Advanced Science Letters, 22, pp.4321-4325.

Manni, C. \& Teng, X.C. (2007). Investigation on the Real Estate Market. What are the Main Factors Influencing the Performance of the French Real Estate Investment Trust. School of Economics, UMEA University, Sweden.

Marshall, D. (1992). Inflation and asset returns in a monetary economy. Journal of Finance, 47(4), pp.315-1343.

NBS (2018). Demographic Statistics Bulletin. Nigerian Bureau of Statistics.

Muller, G.R. \& Pauley, K.R. (1995). The Effects of interest Rate Movements on Real Estate Investment Trusts. Journal of Real Estate Research, 10(3), pp.319-325.

Newell, G. (1996). The Inflation Hedging Characteristics of Australian Commercial Property 1984-1995. Journal of Property Finance, 7, pp.6-20.

Newell, G., Adair, A. \& Nguyen, T.K. (2013). The significance and performance of French REITs (SIICs) in a mixed asset portfolio. Journal of Property Investment and Finance, 31(6), pp.575-588.

Newell, G. \& Osmadi, A. (2009). development and preliminary performance of Islamic REIT in Malaysia. Journal of Property Research, 26(4), pp.329-347.

Nittayagasetwat, A. \& Buranasiri, J. (2012). Real estate investment performance: The test of the impact of additional interest rate information from CIR model. International Journal of Business and Social Science, 3(12), pp.134-143.

Ngerbo-A, T.A. (2016). Monetary policy and inflation in Nigeria. International Journal of Finance and Accounting 5(2), pp.67-76

Nwoko, N.M., Ihemeje, J.C. \& Anumadu, E. (2016). The Impact of Monetary Policy on Economic Growth of Nigeria. AFrican Research Review, 10(3), pp.192-206.

Ojetunde, I. (2013). Revisiting the interaction between the Nigerian residential property market and the macro-economy. Paper presented at the International Federation of Surveyors Working Week. Available at: http://www.fig.net/pub/monthly-articles/may

Olaleye, A., Bello, O.B. \& Ayodele, T.O. (2015).Determinants of Listed Property Stock Prices in Nigeria: A Macreconomic Perspective. Real Estate Finance, 32 (2), pp.70-76. 
Olanrele, O.O., Fateye, O.B. \& Adegunle, T.O. (2017). Microeconomic Determinants of Real Estate Investment Trusts (REIT's) Dividend Return in Nigeria. A paper presented at the 17th Africa Real Estate Society (AfRES) Annual Conference. Johannesburg, South Africa.12-15 September

Olanrele, O.O., Said, R. \& Daud, N.M. (2015). Comparison of REIT dividend performance in Nigeria and Malaysia. African Journal of Business Management, 9(16), pp.608-614.

Olanrele, O.O., Said, R. \& Daud, M.N. (2014). Real estate Investment trust (REIT) in Nigeria: The influence of external factors on return. 14th Africa Real Estate Society (AfRES) Annual Conference. Cape Town, South Africa. 2-5 September 2014.

Oluwofeso, E.O., Adeleke, A.O. \& Udoji, A.O. (22015). Impact of Private Sector Credit on Economic Growth in Nigeria. Journal of Applied Statistics, 6(2), pp.81-101.

Ong, T.S., The, B.H. \& Chong, M.P. (2011). A Study on the Performance of Malaysian Real Estate Investment Trusts from 2005-2010 by using Net Asset Value Approach. International Journal of Economics and Finance, 2(1), pp.1-15.

Oni, A.O., Emoh, F.I. \& Ijasan, K.C. (2011). The impact of money market indicators on real estate finance in Nigeria. Sri Lankan Journal of Real Estate, 6, pp.16-37.

Onyiewu, C (2012). Monetary policy and economic growth of Nigeria. Journal of Economic and Sustainable Development, 3(7), pp.62-70

Oyewole, M.O. \& Ajayi, C.A. (2014). Influence of macroeconomic factors on the performance of office properties in Lagos, Nigeria. Journal of Property Research \& Construction, 2(1), pp.40-48.

Pham A.K. (2013). An empirical analysis of real estate investment trust in Asia: Structure, performance and strategic investment implication. PhD Thesis, University of Western Sydney.

Rigobon, R., Sack, B., (2004). The impact of monetary policy on asset prices. Journal of Monetary Economics, 51 (8), pp.1553-1575.

Rozman, T.A., Azmi, A.N., Najib, R.N.M. \& Ali, M.H. (2015). The potential of Islamic real estate investment trusts in Malaysia. PERINTIS EJournal, 5(2), pp.13-30.

Swanson, Z., Theis, J. \& Casey, K.M. (2002). REIT risk premium sensitivity and interest rate. Journal of Real Estate Finance and Economics, 24(3), pp.319-330.

Tsai, I.C. (2015). Dynamic information transfer in the United States housing and stock market. The North American Journal of Economics and Finance, 34, pp.215-230.

Udude, C.C (2014). Monetary policy and economic growth of Nigeria (19812012). Journal of Policy and Development Studies, 9(1), pp.234-247.

Ufoeze, L.O., Odimgbe, S.O., Ezeabalisi, V.W. \& Alajekwu, U.B. (2018). Effect of Monetary Policy on Economic Growth in Nigeria: An Empirical Investigation. Economic Series, 2, pp.123-140.

Were, M., Nzomoi, J. \& Rutto, N. (2012). Assessing the Impact of Private Sector Credit on Economic Performance. Ecidence from sectoral panel data for Kenya. International Journal of Economics and Finance, 4(3), pp.182-190. 
Victoria, A., Babajide, A.A., Akhanolu, I.A. \& Tochukwu, O. (2016). Monetary Policy and its Effectiveness on Economic Development in Nigeria. International Business Management, 10(22), pp.5336-5340.

Wurstbauer, D. \& Schafers, W. (2015). Inflation hedging and protection characteristics of infrastructure and real estate assets. Journal of property Investment and Finance, 33(1), pp.19-44.

Yan, N. (2019). Study on the Influence of Monetary Policy on Real Estate Price in China. Journal of Service Science and Management, 12, pp.152-171.

Yunus, N. (2012). Modelling Relationship among Securitised Property Markets, Stock Markets and Macroeconomic Variables. Journal of Real Estate Research, 34(2), pp.127-156. 